\title{
Comet Assay and Applications
}

\author{
Ramazan Uzen (Corresponding author's) \\ Department of Medical Biology, Faculty of Medicine, Erciyes University, Kayseri, Turkey \\ E-mail: r-uzen@yandex.com. \\ Ayse Gaye Tomatir \\ Department of Medical Biology, Faculty of Medicine, Pamukkale University, Denizli, Turkey \\ Nurhan Cucer \\ Department of Medical Biology, Faculty of Medicine, Erciyes University, Kayseri, Turkey \\ Hamiyet Donmez-Altuntas \\ Department of Medical Biology, Faculty of Medicine, Erciyes University, Kayseri, Turkey
}

\begin{abstract}
Currently, humans and other living things can have many genotoxic damages due to reasons such as chemicals, drugs, unfavorable environmental effects. Breaks in the DNA structure due to genotoxic damage can cause mutations, changes in chromosome structure and cancer. Comet assay, also known as a single cell gel electrophoresis (SCGE), is a sensitive, rapid and cheap method used to measure DNA damage and repair at the individual cell level. With this method, cells are called this way because of they appear as comets under a microscope.

DNA damage and repair can be detected in each cell type that can be obtained as single cell suspension, with comet assay. In addition to the direct determination of DNA damage in a single cell, it is possible to determine whether all cells in a population suffer from the same amount of damage. Furthermore, this assay may help to predict the heterogeneous response of cells during any treatment, and the tumor response in radiotherapy and chemotherapy treatment protocols. Especially in human biomonitoring studies, it is also used in the investigation of DNA damage in people who exposed to various occupational or accident-related environmental or workplace-related agents.

In this review, a general overview of the comet assay and its currently applications to determine the genotoxicity of environmental factors and chemicals are discussed.
\end{abstract}

Key words: DNA damage, DNA repair, genotoxicity, comet assay, single cell gel electrophoresis.

DOI: $10.7176 / J S T R / 5-5-02$

\section{Komet Yöntemi ve Uygulamaları}

\section{ÖZET}

Günümüzde insanlar ve diğer canlılar kimyasal maddeler, ilaçlar, olumsuz çevre etkisi gibi nedenlerden dolayı birçok genotoksik hasara uğrayabilmektedir. Genotoksik hasar nedeniyle DNA yapısında oluşan kırıklar, mutasyonlara, kromozom yapısında değişikliklere ve kansere neden olabilmektedir. Komet yöntemi, başka bir deyişle tek hücre jel elektroforezi (Single cell gel electrophoresis; SCGE); tek bir hücre düzeyinde DNA hasarını ve tamirini ölçmek amacıyla günümüzde kullanılan hassas, hızlı ve ucuz bir yöntemdir. $\mathrm{Bu}$ yöntemle hücreler mikroskop altında kuyruklu yıldız şeklinde göründükleri için bu şekilde adlandırılmaktadır.

Komet yöntemi ile, DNA hasarı ve tamiri, tek hücre süspansiyonu şeklinde elde edilebilen her hücre tipinde tespit edilebilir. Tek bir hücrede DNA hasarının doğrudan tayininin yanı sıra bir popülasyondaki tüm hücrelerin aynı oranda hasara uğrayıp uğramadığının da tayinine olanak sağlamaktadır. Ayrıca bu yöntem, herhangi bir tedavi sırasında hücrelerin heterojen cevabının, radyoterapi ve kemoterapi tedavi protokollerindeki tümör cevabının öngörülmesine de yardımcı olabilmektedir. Özellikle insan izleme 
çalışmalarında, mesleki veya kaza sonucu olan çevresel veya işyeri kaynaklı çeşitli ajanlara maruz kalan kişilerde DNA hasarının incelenmesinde de kullanılmaktadır.

$\mathrm{Bu}$ derlemede, çevresel etmenlerin ve kimyasalların oluşturduğu genotoksisiteyi belirlemek üzere günümüzde kullanılan komet yöntemi ve uygulamaları tartışılmıştır.

Anahtar sözcükler: DNA hasarı, DNA tamiri, genotoksisite, komet yöntemi, tek hücre jel elektroforezi

\section{Giriș}

Günümüzde insanlarda ve canlılardaki çeşitli sitotoksik ve genotoksik ajanlara maruziyet, DNA üzerinde yapısal değişikliklere ve DNA zincirinde kopmalara ve kansere neden olmaktadır. DNA yapısının değişiminin, kimyasal, fiziksel ve biyolojik ajanlarla etkileşime girerek, mutasyona, apoptoza ve kanser oluşumuna neden olabileceği bilinmektedir (Araldi ve ark. 2015). Oluşan DNA hasarlarını belirlemek üzere, kromozom anomalileri (KA), kardeş kromatid değişimi (KKD), mikronükleus (MN), $\gamma$-H2AX fokus ve komet gibi birçok genotoksisite yöntemi kullanılabilmektedir. Genotoksisite testleri, mevcut kanserojenlerin etkilerinin pek çoğunun hassas bir şekilde belirlenmesini kolaylaştırır. Canlı hücrelerde, genotoksik olmayan kanserojenlerin veya kimyasalların etki mekanizmasının çeşitliliğinden dolayı, kanserojen potansiyelinin öngörülmesi zordur. Farklı testlerin kombinasyonları, genotoksik ve genotoksik olmayan kanserojenlerin daha iyi belirlenmesine olanak sağlar (Bhagat 2018, Trzeciak ve ark. 2008).

Komet yöntemi, hem in vivo hem de in vitro olarak, toksinlere, fiziksel ajanlara, kanserojenlere ve kimyasallara maruziyette genotoksisitenin değerlendirilmesinde kullanılmaktadır. Bu yöntem canlı hücrelerde ve hücresel olmayan DNA hasar tespiti gibi minimal değişim düzeyleri için de ayrıca sıklıkla kullanılmaktadır (Fairbairn ve ark. 1995, Dinçer ve Kankaya 2010, Cortés-Gutiérrez ve ark. 2012, Araldi ve ark. 2015). Komet yöntemi, tek hücre jel elektroforezi (Single cell gel electrophoresis; SCGE) olarak da bilinir (Bhagat 2018). Komet yöntemi çok az sayıda hücre gerektirdiğinden; küçük hacimde insan biyopsi örneklerinde, deney hayvanlarının herhangi bir dokusunda, DNA hasarının boyutlarını saptamada kullanışlı bir araçtır. Ayrıca bu yöntemde işlem hızlıdır, birkaç saat içinde tamamlanır ve duyarlılı̆ı, aynı amaçla kullanılan diğer testlere göre daha yüksektir. Komet yöntemi, DNA hasarı, tamiri ve mekanizmalarını pek çok deneysel şartlarda inceler; tek hücre süspansiyonu şeklinde elde edilebilen ökaryotik ve prokaryotik hücrelerde DNA kırık ve tamirini tespit edebilir. Tek hücre jel elektroforez yöntemi, tek bir hücrede DNA hasarının doğrudan tayininin yanı sıra bir popülasyondaki tüm hücrelerin aynı oranda hasara uğrayıp uğramadığının da tayinine olanak sağlar (Durmaz ve ark. 2010). Herhangi bir tedavi sirasında hücrelerin heterojen cevabının, radyoterapi ve kemoterapi tedavi protokollerindeki tümör yanıtının öngörülmesine de yardımcı olabilmektedir. Özellikle izleme çalışmalarında mesleki veya kaza sonucu olarak çevresel veya işyeri kaynaklı çeşitli ajanlara maruz kalan kişilerde DNA hasarının incelenmesinde de kullanılmaktadır. Komet yöntemi, çeşitli tekniklerle karşılaştırıldığında düşük seviyelerdeki DNA hasarını algılamak için oldukça hassas bir yöntemdir. Dahası, proliferatif olan ya da olmayan hücrelerle, az sayıda olsalar bile nispeten kısa bir süre zarfinda sonuçlar elde edilebilmektedir. Ayrıca komet yöntemi gözyaşı kanalı epitel hücreleri, lens epiteli, yanak epitel hücreleri, burun epitel hücreleri, periferik kan mononükleer hücreler, spermler, biyopsi dokuları gibi çok çeşitli hücrelerde DNA hasarını ve tamir verimliliğini değerlendirmek üzere çok yönlü kullanılan bir yöntemdir (Gunasekarana ve ark. 2015).

$\mathrm{Bu}$ derlemenin amacı, günümüzde birçok toksikolojik kimyasal ajanların ve çevresel etmenlerin oluşturduğu genotoksisitenin değerlendirilmesinde komet yöntemi uygulamalarını tartışılmıştır.

\section{Komet Yöntemi}

Komet yöntemi, hücre düzeyinde meydana gelebilecek DNA hasarını (DNA iplik kırıkları ve tamamlanmamış eksizyon tamir bölgelerini) ölçmek amacıyla günümüzde çok fazla kullanılan ucuz ve hassas bir yöntemdir. Bu yöntemle hücreler mikroskop altında kuyruklu yıldıza benzer biçimde görüldüğü için bu şekilde adlandırılmaktadır (Poli ve ark. 1999, Cemeli ve ark. 2009, Dikilitaş ve Koçyiğit 2010). İlk kez 1978'de Rydberg ve Johanson tarafından, oluşan DNA hasarını ölçmek için, daha sonrasında Ostling ve Johanson (1984) tarafindan geliştirilerek ve nötral $\mathrm{pH}(\mathrm{pH}<8,3)$ lizis tamponu uygulanarak DNA çift ipliklerin hasarını tayin etmek için kullanılmıştır (Ostling ve Johanson 1984, Simoniello ve ark. 2009). Singh ve ark. (1988) bu tekniği geliştirmeye yönelik bazı değişiklikler yaparak, alkali lizis ortamında daha iyi sonuçlar verecek şekilde uygulamalar yapmışlardır. Günümüzde en yaygın olarak kullanılan komet yöntemi de bu alkali komet yöntemidir. Alkali komet yöntemi standart protokolü geniş çapta uygulansa da tüm DNA hasar tespiti için kullanılmamaktadır. Bu protokolün kullanımı,

$10 \mid \mathrm{P}$ a g e 
işaretli DNA kırıklarının belirlenmesine olanak tanımaktadır. Alkali komet yöntemi genetik toksikoloji, nanomateryal genotoksisitesi, moleküler kanser epidemiyolojisi, DNA hasar sistem çalışmaları, mezenşimal kök hücre ve spermatozoidlerde, bitki ve bakterilerde lizis çalışmaları gibi birçok alanda kullanılmaktadır (Dinçer ve Kankaya 2010, Söylemez ve ark. 2012, İnanan ve ark. 2016). Alkali lizis ortamında ( $\mathrm{pH}>13)$ DNA tek iplik kırıkları, çift iplik kırıkları, tamamlanmamış eksizyon tamir bölgeleri, çapraz bağlar, alkali ortamda açığa çıkan hasarlar gibi DNA hasar tespitine yönelik çalışmalar yapılabilmektedir. Komet yöntemi, 2003 yılında Hartmann ve ark. tarafindan "Genotoksisitede test prosedürleri uluslararası çalıştayı" ve 2007 yılında Burlinson ve ark. tarafından "Genotoksisite testleri uluslararası 4. Çalıştayı" nda protokolü standardize edilerek, yaygın bir şekilde kullanılmaya devam edilmektedir (Ostling ve Johanson 1984, Simoniello ve ark. 2009, Colins ve ark. 2014, Kumar ve ark. 2018, OECD/OCDE 489 2016).

Yöntem, hücrelerin izolasyonu, slaytların hazırlanması, lizis aşaması, DNA sarmalının çift ipliklerine çözülmesi, elektroforezde yürütülmesi, nötralizasyon işleminin yapılması, slaytların boyanması ve son olarak bilgisayar ortamında verilerin analizi basamaklarından oluşur (Fidan 2008, Dikilitaş ve Koçyiğgit 2010) (Şekil 1). Komet yöntemi, meydana gelen kimyasal, fiziksel, oksidatif reaktifler nedeniyle oluşan sitotoksik ve genotoksik ajanların hücreler üzerinde canlı etkilerini incelemeye olanak tanımaktadır. Böylece organizmaların hücre düzeyindeki DNA hasarının tespit edilmesine olanak sağlar (Raiaguru ve ark. 2003, Cortés-Gutiérrez ve ark. 2012, Ren ve ark. 2017). Komet yönteminde, canlı dokulardan elde edilen hücrelerin izolasyonu sağlanarak ince bir agaroz jel içine tespit edildikten sonra, elektriksel bir alanda yürütülür. Genotoksisiteye maruz kalan hücre içindeki DNA yürütülme aşamasında DNA tamir mekanizması tarafindan tamir edilmemişse, DNA hasarı sonucu meydana gelen DNA tek ve çift iplik kırıkları elektriksel alanda, farklı molekül ağırlıklarına ve elektrik yüklerine göre farklı hızlarda göç ederler. Daha sonra slaytlar etidyum bromür ile boyanır, floresan mikroskop altında incelenerek DNA hasar derecelerine göre oluşan kuyruklu yıldıza benzer bir şekil alan DNA görüntülerinin analizleri yapılır (Söylemez ve ark. 2012, Ünlü ve Sağlar 2012). Komet görüntüsü, oluşan DNA hasarına göre derecelendirilir. Hasar olmaması ya da minimum hasar durumu "kategori 0" olarak kabul edilir, hasar oluşan DNA'ları içeren komet görüntüleri ise az hasarlı, orta derecede hasarlı ve çok hasarlı olmak üzere 4 kategoride değerlendirilir (Şekil 2) (Söylemez 2011).

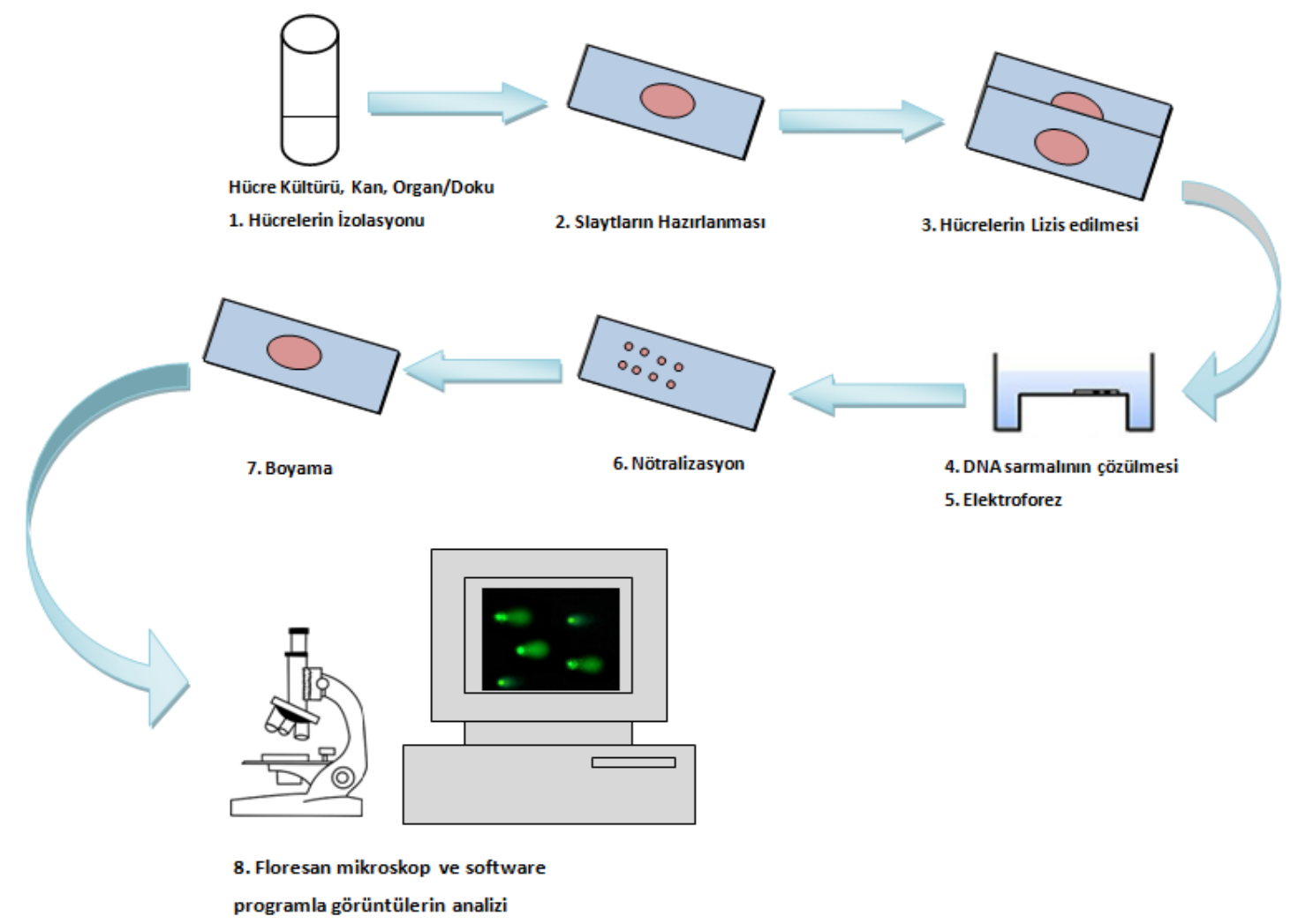

Şekil 1: Alkali komet yöntemi genel basamakları. 
Yöntemdeki DNA hasar parametreleri, genellikle kuyruk uzunluğu ve kuyruk momenti, kuyrukta oluşan DNA yüzdesi, DNA baş uzunluğu ve tüm baş kısmın yoğunluğu ve kuyruklu hücrelerin yüzdesinin belirlenmesi ile yapılır. Bu analizler yapılırken, hasar ve tamir tespiti ve parametrelerinin belirlenmesi ve değerlendirilmesi için çeşitli yazılımlar kullanılır. Komet yöntemi için geliştirilen bu bu yazılımlar vasıtasıyla her bir hücre için fotoğraflama ve ölçüm yapılır (Işıkçı 2007, Dikilitaş ve Koçyiğit 2010). DNA hasar mekanizmalarını belirlemek üzere günümüzde kullanılan iki komet (alkali ve nötral) yöntemi aynı görünmesine rağmen uygulamada aralarında $\mathrm{pH}$ değerleri açısından farklılık göstermektedir. Alkali komet yöntemi pH'ın yüksek (>13) olduğu, DNA hasarı ve tamir mekanizmasının DNA'nın hem tek hem de çift iplik kırık seviyesinde analiz edilmesine olanak sağlar. Nötral komet yöntemi ise pH'ın 9.5 olduğu bir ortamda uygulanır ve bu yöntem DNA hasar ve tamirinde DNA'nın sadece çift iplik kırıklarının analizine izin verir. Bu yüzden günümüzde DNA hasarının ölçümü için daha çok alkali komet yöntemi kullanılır (Güner ve Gökalp-Muranlı 2013, OECD/OCDE 489 2016).
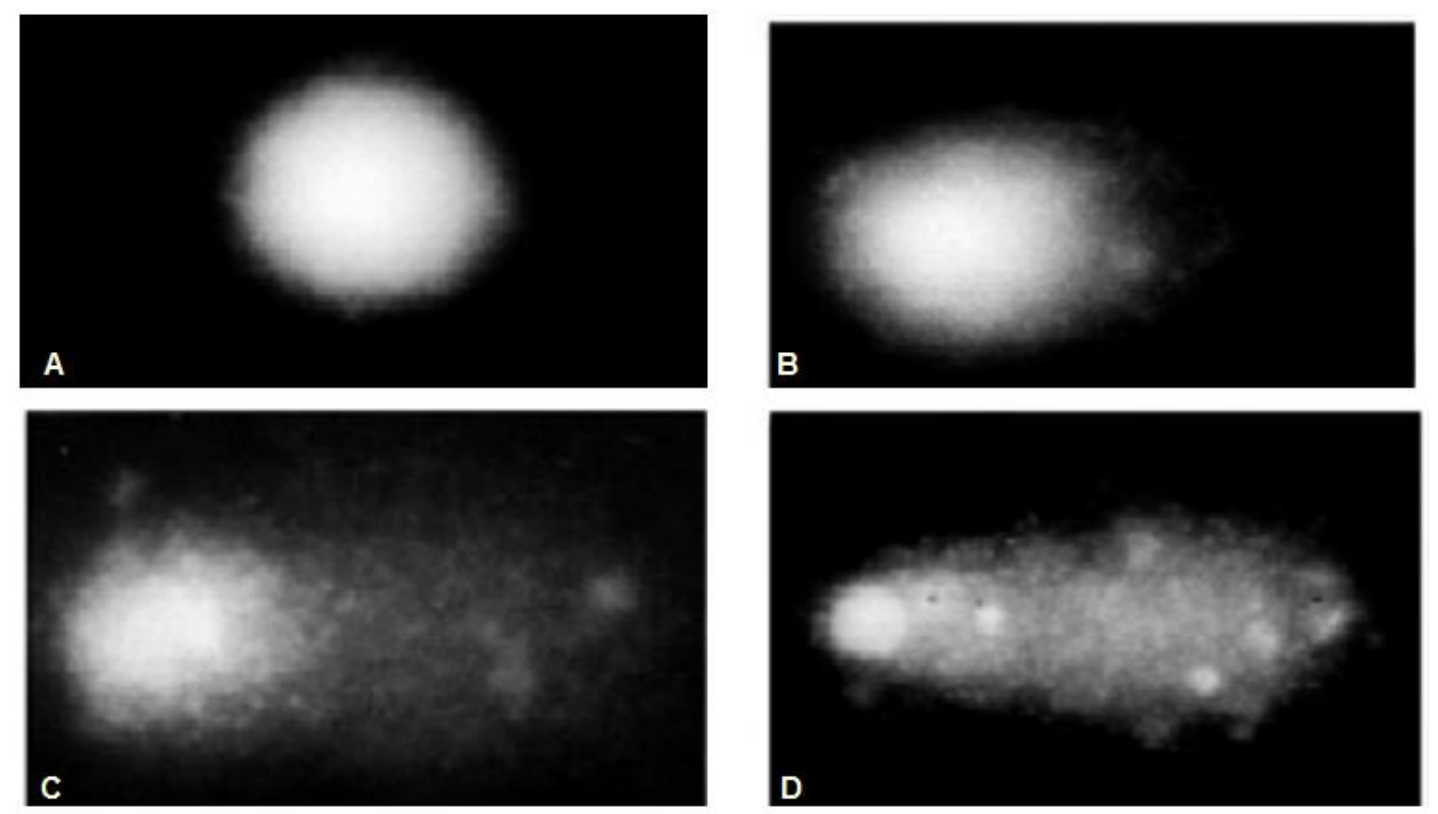

Şekil 2: Komet görüntülerinin, oluşan DNA hasarına göre derecelendirilmesi. Kategori 0: Hasarsız ya da minimum hasar (A); Kategori 1: Az hasarlı (B); Kategori 2: Orta derece hasarlı (C); Kategori 3: Çok hasarlı (D) (Söylemez 2011'den modifiye edilmiştir)

\section{Komet Uygulamaları}

İnsan vücut hücreleri, sürekli olarak DNA'da hasara yol açabilecek tehlikeli maddelere maruz kalmaktadır. Çeşitli kimyasal, fiziksel ve biyolojik ajanları içine alan bu genotoksik maddeler, kanseri de içeren birçok hastalıklarla ilişkili olan genomik karasızlığa ve çoklu mutasyonlara sebep olur. Genel olarak genotoksik maddeler birçok genetik hasarı doğrudan yada dolaylı olarak indükler ve karsinogenez sürecinde önemli bir rol oynar. Komet yöntemi herhangi bir hücre tipinde in vivo veya in vitro genotoksisitenin belirlenmesinde kullanılan hızlı bir yöntemdir (Pellegri ve ark. 2014).

Oksidatif stres, hücrelerde üretilen reaktif oksijen türlerinin (ROS) miktarı, normal detoksifikasyon sistemlerinin kapasitesini aştığında ortaya çıkar. ROS'leri, DNA'da 20'den fazla oksidatif baz hasar ürününün oluşmasına yol açabilmekte ve çeşitli mutasyonlara neden olmaktadır. Hasara uğramış olan DNA bazları arasında 8-hidroksi-2'-deoksiguanozin (8-OHdG) en duyarlı ve sık karşılaşılan oksidatif DNA hasarı belirtecidir (Fidan 2008, Atmaca ve Aksoy 2009). Oksidatif oksijen türlerin kanserli hücrelerde DNA hasarı oluşturmasının normal hücrelere göre daha fazla olduğu rapor edilmiştir. Reaktif oksijen türlerinin mitokondriyal solunum zinciriyle sürekli üretilmesi ve salınması nükleik asit, protein ve lipid gibi biyomoleküllerin hasarına ve çeşitli hastalıkların oluşumuna neden olabilmektedir. Ayrıca oksidatif hasar oluşumu, sigara dumanı, radyasyon, kömür, dizel, krom, ilaçlar, asbest, gibi çevresel faktörlere maruz kalındığında da ortaya çıkabilmektedir. Hücrede biriken oksidatif hasar türleri gen regülasyonunu bozarak yaşlanma veya apoptotik süreçleri de tetikleyebilmektedir. Hücresel 
metabolizma tarafindan üretilen serbest radikaller veya endojen kaynaklı ajanlar DNA kırılmalarına neden olarak, replikasyon ve rekombinasyon sırasında DNA hasarının oluşmasına neden olabilmektedir (Collins 2009, Karsl1-Çeppioğlu ve Yurdun 2012, Söylemez ve ark. 2012, Milic ve ark. 2015, Foto ve ark. 2017, Li ve ark. 2018). Komet yöntemi, insan hastalıklarının oluşumuna çok sık neden olan oksidatif stres altında gerçekleşen oksidatif DNA hasarını ve genomik kararsızlığı ölçmede, ayrıca ilgili genlerde oluşabilecek polimorfizmin ve genetik hasarın çevresel faktörlerle etkileşiminin incelenmesinde de sıklıkla kullanılmaktadır.

Pestisitlerin de gerek evde kullanımı ve gerekse zirai çalışmalarda kullanımı açısından halk sağlığ üzerine önemli etkileri bulunmaktadır. Pestisitlerin yine aşırı dozda kullanımının kanserojen bir etkiye sahip olduğu bilinmektedir. Yapılan çalışmalarda en düşük dozda dahi periferal kan hücrelerinde yüksek DNA hasarına neden olduğu komet yöntemiyle gösterilmiştir (Dikilitaş ve Koçyiğit 2010).

Sitogenetik ve genotoksisiteye neden olan çeşitli metaller, reaktif oksijen türleri, pestisitler gibi bazı kimyasallar DNA hasarına neden olmaktadır. Komet yöntemi, DNA hasar ve tamirine duyarlılı̆̆ sayesinde hızlı sonuç alınması, uygulanması için gereken örnek miktarının az olması ve düşük maliyetle gerçekleştirilmesinden dolayı sitogenetik ve genotoksisite çalışmalarında kullanılmaktadır. Ayrıca, DNA tamir çalışmaları, biyolojik izleme, klinik araştırma alanları, antioksidan araştırmaları, apoptoz araştırmaları gibi çok çeşitli uygulama alanlarına sahiptir (Durmaz ve ark. 2010, Tozan-Beceren ve ark. 2011).

\section{Komet Uygulamasını Etkileyen Faktörler}

DNA hasarının hem in vivo hem de in vitro olarak, tek hücre seviyesinde basit, hassas ve ekonomik ölçümüne izin veren komet yönteminin geçerliliği ve güvenilirliği çeşitli faktörlerden etkilenebilmektedir. Komet uygulaması sırasında dikkat edilmesi gereken ve elde edilecek sonuçların hassasiyetini etkileyen faktörler arasında, agaroz konsantrasyonu, süre, sıcaklık, verilen elektrik akımı, $\mathrm{pH}$ konsantrasyonu, lizis solusyon koşulları, ortamın ışık düzeyi gibi noktalar sıralanabilir. Jeldeki agaroz konsantrasyonu komet yöntemini etkileyebilir, daha düşük konsantrasyon daha fazla kuyruk uzunluğuna yol açabilir. Lizis süresi minimum etkiye sahip olsa da, alkali inkübasyon süresi önemli bir rol oynar (Azqueta ve Collins 2013) . Kuyruktaki DNA yüzdesi, alkali solusyondaki süreye bağlı olarak artar. Kuyruktaki DNA yüzdesi ve komet kuyruk uzunluğu üzerinde en büyük etkiye sahip olan parametreler, elektroforez voltaj gradyanı, süresi ve sıcaklıktır. Sinırlar dahilinde, komet kuyruk uzunluğu ve yoğunluğu, elektroforezin uygulama süresi ve voltajla orantılı olarak artar. Elektroforezin soğuk bir odada çalıştırılması, böylece tank sıcaklığının $15^{\circ}$ C'nin altında tutulması önerilmektedir (Azqueta ve Collins 2013). Komet yöntemi uygulanırken, standartlaştırılmış bir protokol takip edilirse optimum sonuçlar elde edilebilir (Gunasekarana ve ark. 2015).

\section{Komet Yöntemi ve Kanser}

Günümüzde olumsuz çevre koşulları, kullanılan ilaçlar, radyasyona maruz kalma, dengesiz beslenme sonucu oluşan metabolizma hastalıkları gibi birçok neden canlılarda genotoksisiteye yol açabilmektedir. Bazı çalışmalar, genotoksisite ve sitotoksisite yöntemlerinin kanserin erken teşhis edilmesi amacıyla bir biyogösterge olarak kullanılabileceğini göstermektedir. Yapılan çalı̧̧malarda da bazı kanser çeşitlerinin belirlenmesi veya tahmin edilmesi komet yöntemi ile kanser risk değerlendirilmesi yüksek bir doğrulukla kanitlanmıştır (Manas ve ark. 2009, Tozan-Beceren ve ark. 2011, Söylemez ve ark. 2012).

Servikal neoplazili kadınlarda komet yöntemiyle DNA tek ve çift iplik kırıklarındaki gözlenen artış ile birlikte genomik kararsılılı gösterilmiştir (Cortés-Gutiérrez ve ark. 2012). Yapılan çalışmalarda, meme, akciğer, prostat, göğüs ve kolon kanseri gibi farklı tümör hücre hatlarında çeşitli dozlarda radyasyon ve radyasyonun etkinliğini ve kanserin farklı evrelerinde radyo-duyarlılığını değerlendirmek için alkali komet yönteminin kullanışı bir yöntem olduğu gösterilmiştir. Böylece standardize edilmiş alkali komet yöntemi, tümör hücrelerinde radyo-duyarlılığın belirlenmesinde ve kanser hastalarında radyoterapi tedavisinin etkinliği ve takibinde önemli bir araç olacaktır (Gunasekarana ve ark. 2015). Akciğer adenokarsinom A549 hücre hattı üzerinde DNA eksizyon tamiri aktivitesi, DNA tamir kinetiği ve bireysel DNA tamir kapasitesinin ölçümü için polimeraz inhibitör afidikolin (APC) kombinasyonu ile komet yöntemi kullanılmıştır. Bu çalışma APC-modifiye komet yönteminin bazı kısıtlamaları olduğunu göstermekle birlikte, yöntemin çeşitli kanser hücre hatlarına uygulanabileceğini de göstermiştir (Speit ve ark. 2016). Genisteinin pankreas kanseri hücre hatları üzerinde antikanser etkileri düzeyi komet analizi ile değerlendirilmiş ve genisteinin doza bağımlı DNA hasarına neden olduğu belirlenmiştir (Bi ve ark. 2018). Kanserin spermatogenez üzerine yan etkilerini araştırmak için; testiküler kanser ve lenfoma tanısı konulan hastaların sperm genomik kalitesi alkali ve nötral komet yöntemleri kullanılarak ölçülmüş ve DNA hasarının fertil kişilerdekine göre artış gösterdiği bulunmuştur (Kumar ve ark. 2018). Başka bir çalışmada, kemoterapi alan meme kanseri hastalarının beyaz kan hücrelerinde tedavi öncesi ve tedavi

13 | P a g e

www.iiste.org 
sonrası indüklenen DNA hasarı, alkali komet yöntemi ile değerlendirilmiş ve alkali komet yönteminin klinik uygulamalarda antineoplastik ilaçların alımından sonra kritik DNA lezyonlarının takibi için uygun bir yöntem olduğu önerilmiştir (Kopjar ve ark. 2006). Komet yöntemi, sadece kanser hücrelerinde DNA tamir seviyelerini ölçmek için değil, aynı zamanda tümörlerde kemo- ve radyo-terapik tedavilerle oluşan DNA hasarını belirlemek için de kullanılan bir yöntemdir.

\section{Sonuç}

Yapılan araştırmalarla nispeten hızlı ve basit bir yöntem olan komet yönteminin, DNA hasarı ve tamiri yönüyle hava, su ve toprak kirliliğine (örneğin pestisitler, dioksinler, elektromanyetik alanlar) sebep olan çevresel ajanların test edilmesinde, çeşitli hastalıkların teşhisinde ve izlenmesinde ve kanser hastalarının takibinde yaygın olarak kullanıldığı gösterilmiştir. Komet yöntemi, ortaya çıkan DNA hasarı ve tamirinin değerlendirilmesi ve analiz edilmesini kolaylaştırmanın yanısıra diğer yöntemlere göre pratik ve ucuz olması yönüyle de büyük bir avantaj sağlamaktadır (Koppen ve ark. 2017). Nihayetinde komet yöntemiyle DNA hasar tespitinde, sinırlı laboratuar olanaklarıyla yüksek bir duyarlılık potansiyeline sahip olup karsinojenlerin neden olduğu genotoksisitenin belirlenmesinde kullanılabilecek duyarlı ve özgül bir yöntem olduğu anlaşılmıştır (Glei ve ark. 2016).

\section{Kaynaklar}

Araldi RP, Correea de Melo T, Thais Mendes TB, PLuiz de Sa Junior P, Heidi B, et al. (2015) Using the Comet and micronucleus assays for genotoxicity studies: A review. Biomedicine \& Pharmacotherapy, 72, 74-82.

Atmaca E, Aksoy A (2009) Oksidatif DNA Hasarı ve Kromatografik Yöntemlerle Tespit Edilmesi. YYU Veteriner Fakültesi Dergisi, 20 (2), 79-83.

Azqueta A, Collins AR (2013) The essential comet assay: a comprehensive guide to measuring DNA damage and repair. Archives Toxicology, 87(6), 949-968.

Bhagat J (2018) Combinations of genotoxic tests for the evaluation of group 1 IARC carcinogens. Journal of Applied Toxicology, 38 (1), 81-99.

Bi YL, Min M, Shen W, Liu Y (2018) Genistein induced anticancer effects on pancreatic cancer cell lines involves mitochondrial apoptosis, G0/G1cell cycle arrest and regulation of STAT3 signalling pathway. Phytomedicine, 39, 10-16.

Cemeli E, Baumgartner A, Anderson D (2009) Antioxidants and the Comet assay. Mutation Research, 681, 51-67.

Collins AR (2009) Investigating oxidative DNA damage and its repair using the Comet assay. Mutation Research, 681, 24-32.

Collins AR, Ma AG, Duthie SJ (1995) The kinetics of repair of oxidative DNA damage (strand breaks and oxidised pyrimidine) in human cells. Mutation Research, 336, 69-77.

Collins A, Koppen G, Valdiglesias V, Dusinska M, Kruszewski M, et al. (2014) The Comet assay as a tool for human biomonitoring studies: The ComNet Project, Mutation Research, 759, 27-39.

Cortés-Gutiérrez EI, Hernández-Garza F, García-Pérez JO, Dávila-Rodríguez MI, Aguado-Barrera ME, et al. (2012) Evaluation of DNA Single and Double Strand Breaks in Women with Cervical Neoplasia Based on Alkaline and Neutral Comet Assay Techniques. Journal of Biomedicine and Biotechnology, 2012, pages 7.

Dikilitaş M, Kocyigit A (2010) Mononuclear Leukocyte DNADamage On Higher Cells Caused By Eco-Friendly Pesticides And Their Analysis Using Casp ${ }^{\circledR}$ Programme. Journal of Agricultural Faculty Harran University, 14(4), 47-56. 
Dinçer Y, Kankaya S (2010) DNA Hasarının Belirlenmesinde Comet Assay. Türkiye Klinikleri Journal of Medical Science, 30(4), 1365-1373.

Durmaz A, Dikmen N, Gündüz C (2010) DNA Hasar Analizinde Tek Hücre Jel Elektroforezi (Komet Yöntemi). ARŞIV, 19, 236.

Fairbairn DW, Olive PL, Oneill KL (1995) The Komet Assay - a Comprehensive Review. Mutation Research-Reviews in Genetic Toxicology, 339, 37-59.

Fidan AF, (2008) DNA Hasar Tespitinde Tek Hücre Jel Elektroforezi. Afyon Kocatepe University Journal of Science, 8 (1), 53-64.

Foto E, Zilifdar F, Yilmaz S, Yalcin İ, Diril N (2017) Assessment of Selectivity of A Serial 1,4Benzoxazine-3-One Derivatives Induced Oxidative DNA Damage on Cancer Cells Using The Modified Alkaline Comet Assay. The Turkish Journal of Occupational / Environmental Medicine and Safety, 2 (1), 303-303.

Glei M, Schneider T, Schlörmann W (2016) Comet assay: an essential tool in toxicological research. Archives Toxicology, 90 (10), 2315-2336.

Gunasekarana V, Raj GV, Chand PA (2015) Comprehensive Review on Clinical Applications of Comet Assay. Journal of Clinical and Diagnostic Research, 9(3), GE01-GE05.

Güner U, Gökalp Muranlı FD, (2013) Balıklarda Tek Hücre Jel Elektroforezi (Comet Assay). Karadeniz Fen Bilimleri Dergisi / The Black Sea Journal of Sciences, 3(9), 103-114.

Hartmann A, Agurell E, Beevers C, Brendler-Schwaab S, Burlinson B, et al. (2003) Recommendations for conducting the in vivo alkaline comet assay. 4th International Komet assay workshop. Mutagenesis, 18 (1), 45-51.

Işıkçı, Y, (2007) Çocuklarda Sevoflurane Ve Desflurane'ın Periferik Lenfositler Üzerine Genotoksik Etkilerinin “ Comet Assay” Yöntemiyle Araştırılması, İstanbul Üniversitesi Cerrahpaşa Tıp Fakültesi, Uzmanlık Tezi: 1-2.

İnanan BE, Yıldırım N, Demirkaya E (2016) Applications of Different Comet Assay (the Single Cell Gel Eelectrophoresis) Methods for Detecting DNA Damage in Cryopreserved Fish Sperm. JAVST, 1(1), 6-13.

Karsl1-Çeppioğlu S, Yurdun T (2012) In Vitro Testing for Genotoxicity of Indigoid Dyes by Comet Assay. MÜSBED, 2(3), 108-112.

Kopjar N, Milas I, Garaj-Vrhovac V, Gamulin M (2006) Alkaline comet assay study with breast cancer patients: evaluation of baseline and chemotherapy-induced DNA damage in non-target cells. Clinical Experiment Medicine, 6(4), 177-190.

Koppen G, Azqueta A, Pourrut B, Brunborg G, Andrew R, et al.(2017) The next three decades of the Comet assay: a report of the 11th International Komet Assay Workshop. Mutagenesis, 00, 1-12.

Kumar K, Lewis S, Vinci S, Riera-Escamilla A, Fino MG, et al. (2018) Evaluation of sperm DNA quality in men presenting with testicular cancer and lymphoma using alkaline and neutral Comet assays. Andrology, 6, 230-235.

Li X, Gu S, Sun D, Dai H, Chen H, et al. (2018) The selectivity of artemisinin-based drugs on human lung normal and cancer cells. Environmental Toxicology and Pharmacology, 57, 86-94.

Manas F, Peralta L, Raviolo J, Ovando HG, Weyers A, et al. (2009) Genotoxicity of glyphosate assessed by the Comet assay and cytogenetic tests. Environmental Toxicology and Pharmacology, 28, 37-41. 
Milic M, Frustaci A, Del Bufalo A, Sánchez-Alarcón J, Valencia-Quintana R, et al. (2015) DNA damage in non-communicable diseases: A clinical and epidemiological perspective. Mutation Research, 776, 118-127.

OECD/OCDE 489 (Adopted: 29 July 2016) OECD Guideline for the testing of chemicals-in vivo mammalian alkaline comet assay, 1-25.

Ostling O, Johanson K J (1984) Microelectrophoretic study of radiation-induced DNA damages in individual mammalian cells. Biochemical and Biophysical Research Communications, 123, 291298.

Pellegri V, Gorbi G, Buschini A (2014) Comet assay on Daphnia magna in eco-genotoxicity testing. Aquatic Toxicolology, 155, 261-268.

Poli P, Buschini A, Spaggiari A, Rizzoli V, Carlo-Stella C, Rossi C (1999) DNA damage by tobacco smoke and some antiblastic drugs evaluated using the Comet assay. Toxicolology Letter, 108, 267-276.

Raiaguru P, Suba S, Palanivel M, Kalaiselvi K (2003) Genotoxicity of a polluted river system measured using the alkaline Comet assay on fish and earthworm tissues. Environmental and Molecular. Mutagenesis, 41, 85-91.

Ren N, Atyah M, Chen WY, Zhou CH (2017) The various aspects of genetic and epigenetic toxicology: testing methods and clinical applications. Journal of Translational Medicine, 15 (110), 1218-1224.

Rydberg B, Johanson KJ (1978) Estimation of DNA strand breaks in single mammalian cells. DNA Repair Mechanism. (Hanwalt PC, and Friedberg, EC. Eds), Academic Press, New York, 465-468.

Simoniello MFF, Gigena G, Poletta A, Loteste E, Kleinsorge M, et al. (2009) Alkaline Comet Assay for Genotoxic Effect Detection in Neotropical Fish Prochilodus lineatus (Pisces, Curimatidae). Bulletin of Environmental Contamination and Toxicology, 83, 155-158.

Singh NP, Mc Coy MT, Tice RP, Schneider EL (1988) A simple technique for quantitation of low levels of DNA damage in individual cells. Experimental Cell Research, 175, 184-191.

Söylemez E (2011) Sigara Kullananlarda Kan Kadmiyum Düzeyi ve Lenfosit DNA Hasarının Belirlenmesi, Ankara Üniversitesi Sağlık Bilimleri Enstitüsü, Yüksek Lisans Tezi. Ss:23.

Söylemez E, Kayaaltı Z, Aliyev V, Söylemezoğlu T (2012) Effect of cigarette smoking on DNA damage according to nine Comet assay parameters in female and male groups. Ankara Üniversitesi Tıp Fakültesi Mecmuası, 65 (1), 39-46.

Speit G, Schütz P, Bausinger J (2016) Different sensitivities of cultured mammalian cells towards aphidicolin-enhanced DNA effects in the Comet assay. Mutation Research, 803-804, 22-26.

Tozan-Beceren A, Omurtag GZ, Yeğen C, Şardaş S (2011) Kolorektal Kanser Tanısı Konmuş Olgularda ve Birinci Derece Yakınlarında DNA Hasarının Araştırılması. Journal of Marmara University Institute of Health Sciences, 1(3), 155-161.

Trzeciak AR, Barnes J, Evans MK (2008) A Modified Alkaline Comet Assay for Measuring DNA Repair Capacity in Human Populations. Radiation Research, 169, 110-121.

Ünlü S ve Sağlar E (2012) Tek hücre jel elektroforez yöntemi için alternatif güvenli boyalar. Cumhuriyet Medical Journal, 34, 393-398. 